\title{
Urinary Concentrating Defect of Adrenal Insufficiency
}

\author{
PERMISSIVE ROLE OF ADRENAL STEROIDS ON THE HYDROOSMOTIC \\ RESPONSE ACROSS THE RABBIT CORTICAL COLLECTING TUBULE
}

\author{
Michael J. Schwartz and Juha P. KoKko, Department of Internal Medicine, \\ University of Texas Health Science Center, Dallas, Texas 75235
}

\begin{abstract}
A B S T R A C T Mineralo- and glucocorticoid-deficient states, such as Addison's disease, are partly characterized by an inability to generate a maximally concentrated urine. The purpose of the present study was to develop a model of adrenal insufficiency and to determine whether changes in the intrinsic function of the collecting duct could partly account for this concentrating defect. Two kinds of experiments were performed: an assessment of the in vivo ability of adrenalectomized rabbits to concentrate their urine, and an examination of the intrinsic hydroosmotic responsiveness of in vitro perfused collecting ducts isolated from normal and adrenalectomized rabbits. The present study demonstrates that adrenalectomized rabbits are unable to concentrate their urine maximally, and that the in vivo administration of either deoxycorticosterone, $250 \mu \mathrm{g} / \mathrm{kg}$, or dexamethasone, $50 \mu \mathrm{g} / \mathrm{kg}$, restored to or toward normal their concentrating ability. When cortical collecting tubules from adrenalectomized rabbits were perfused in vitro, they demonstrated a markedly blunted hydroosmotic response to antidiuretic hormone (ADH), which was corrected by the in vitro addition of either aldosterone $(50 \mathrm{pM})$ or dexamethasone $(50 \mathrm{pM})$, but not progesterone $(50 \mathrm{pM})$. The steroids by themselves, in the absence of $\mathrm{ADH}$, had no intrinsic effect on the water permeability of the collecting duct. The blunted hydroosmotic response across cortical collecting tubules from adrenalectomized rabbits was corrected by the addition of either 8-bromo cyclic AMP or a potent phosphodiesterase inhibitor, 1-methyl-3-isobutylxanthine. The present studies show that the cortical collecting tubules obtained from adrenalectomized rabbits do not respond normally to $\mathrm{ADH}$. The poor hydroosmotic response to $\mathrm{ADH}$ was corrected by exogenous aldos-
\end{abstract}

Portions of this work were submitted in partial fulfillment for the requirements of the Ph.D., Case Western Reserve University, Cleveland, Ohio.

Received for publication 3 October 1979 and in revised form 16 April 1980. terone, dexamethasone, an analog of cyclic AMP, or a phosphodiesterase inhibitor. In conclusion, the present studies are consistent with the view that the concentrating defect seen in adrenal insufficiency is at least partly the result of the absence of the permissive effect that adrenal steroids exert on the ADH-induced reabsorption of water across the collecting duct. The absence of adrenal steroids results in a diminished rate of cyclic AMP accumulation in the cells of the collecting duct, either as a result of an augmented activity of cyclic AMP phosphodiesterase or a diminished rate of cyclic AMP generation.

\section{INTRODUCTION}

Addisonian patients who are gluco- and mineralocorticoid deficient are characterized by numerous derangements in the regulation of salt and water excretion: decreased plasma volume as a result of inappropriate natriuresis; hyperkalemic acidosis as a result of decreased excretion of hydrogen and potassium; inability to excrete normally a free water load (1-3); and decreased ability to generate a maximally concentrated urine (4). Whereas the first three derangements have been examined in some detail previously, the mechanism by which urine cannot be concentrated maximally has not received the same scrutiny. The purpose of the present studies was to examine the role of the collecting duct in the inability to form maximally concentrated urine in a gluco- and mineralocorticoid-deficient state. Specifically, the present studies were designed to examine whether adrenal steroids by themselves influence the intrinsic osmotic water impermeability of the collecting duct, and to determine whether an altered hydroosmotic response of the collecting duct to antidiuretic hormone $(\mathrm{ADH}),{ }^{1}$ in the absence of adrenal

\footnotetext{
${ }^{1}$ Abbreviations used in this paper: $\mathrm{ADH}$, antidiuretic hormone; $J_{v}$, rate of net volume flux in $\mathrm{nl} / \mathrm{mm} \mathrm{min} ; \mathrm{L}_{\mathrm{p}}$, hydraulic conductivity coefficient; MIX, 1-methyl-3-isobutylxanthine; PGE, prostaglandin E.
} 
steroids, could contribute to the concentrating defect seen in this setting. Further, through the use of in vitro microperfusion techniques, we have examined the modulation of the intrinsic hydroosmotic responsiveness of the cortical collecting tubule to ADH by adrenal steroids.

\section{METHODS}

Adrenalectomy. Female New Zealand white rabbits weighing $1.5-2.5 \mathrm{~kg}$ were anesthetized with an intramuscular injection of $50 \mathrm{mg} / \mathrm{kg}$ ketamine plus $3.5 \mathrm{mg} / \mathrm{kg}$ promazine (ketaset plus; Bristol Myers Company, Syracuse, N. Y.) and adrenalectomized under microscopic control via a midline abdominal incision. No accessory adrenal tissue was seen. Postoperatively, each animal was administered a single intramuscular injection of dexamethasone phosphate (hexadrol phosphate; Organon Inc., West Orange, N. J.), $50 \mu \mathrm{g} / \mathrm{kg}$, and maintained thereafter on $0.9 \%$ sodium chloride drinking fluid, without additional exogenous steroid. The adequacy of adrenalectomy was assessed by the measurement of plasma corticosterone concentrations by radioimmunoassay (Endocrine Science, Tarzana, Calif.). In seven adrenalectomized rabbits, 2 wk after surgery the plasma corticosterone concentration was $38 \pm 5 \mathrm{ng} / \mathrm{dl} .{ }^{2}$ This was in contrast to the plasma corticosterone concentration of $2,501 \pm 491 \mathrm{ng} / \mathrm{dl}$ similarly obtained in four normal rabbits. All adrenalectomized rabbits were studied $10 \mathrm{~d}-2 \mathrm{wk}$ after surgery.

Maximum urinary concentrating ability. 6 normal and 12 adrenalectomized rabbits, all drinking $0.9 \%$ sodium chloride, were adapted to metabolic cages. Urine was collected under water-equilibrated mineral oil starting $2 \mathrm{~h}$ after the intramuscular injection of $1.25 \mathrm{U} / \mathrm{kg}$ of vasopressin tannate in oil (pitressin; Parke, Davis \& Co., Detroit, Mich.). After $8 \mathrm{~h}$ of collection, the osmolality of the urine was determined by freezing point depression (advanced osmometer; Advanced Instruments, Inc., Needham Heights, Mass.). 1 wk later, the same 12 adrenalectomized rabbits were restudied to determine whether the replacement of either mineralo- or glucocorticoid steroid hormone improved the urinary concentrating ability. Each rabbit was given an intramuscular injection of either deoxycorticosterone acetate in oil (Percorten; Ciba-Geigy Corp., Pharmaceuticals Div., Summit, N. J.), $250 \mu \mathrm{g} / \mathrm{kg}$, or dexamethasone phosphate, $50 \mu \mathrm{g} / \mathrm{kg}$; $2 \mathrm{~h}$ later the maximum urinary osmolality after vasopressin was determined as before.

In vitro microperfusion. The technique of in vitro microperfusion used in the present study was similar to that previously reported (5); only the salient features will be described. Rabbits were decapitated, and a $1-2-\mathrm{mm}$ coronal slice of kidney was placed on ice in a dish containing a solution of artificial ultrafiltrate, the composition of which was identical to that of the solution bathing the outside of the tubules in vitro (see below) except that the dissecting solution additionally contained $5 \mathrm{mg} / \mathrm{ml}$ of bovine serum albumin. Cortical collecting tubules were dissected from the slice, with special care being taken so that the proximal end of all tubules began immediately below the superficial branchpoint of the collecting duct; the distal end of the tubule was clearly located within the cortex of the kidney.

Cortical collecting tubules were transferred to a Lucite chamber sitting on the stage of an inverted microscope and the ends cannulated within concentric glass micropipettes. Hydraulic insulation of the ends of the tubules within the

${ }^{2}$ The limit of detection by this assay is $20 \mathrm{ng} / \mathrm{dl}$. pipettes was assured by the use of Sylgard 184 (Dow Corning Corp., Midland, Mich.). The solution used to bathe the outside of the tubule was an artificial ultrafiltrate with the following composition, $(\mathrm{mM}): \mathrm{NaCl} 115 ; \mathrm{KCl} 5, \mathrm{NaHCO}_{3} 25$; $\mathrm{NaH}_{2} \mathrm{PO}_{4} 2.3$, Na acetate 10; $\mathrm{MgSO}_{4}$ 1, glucose 8; alanine 5 ; $\mathrm{CaCl}_{2}$ 1.8. No protein was present in the bathing solution. The solution used to perfuse the lumen of the tubule was of an identical electrolyte composition to the bathing solution, except that the concentration of $\mathrm{NaCl}$ was $10 \mathrm{mM}$. Thus, the final osmolality of the perfusate was $120 \mathrm{mosM}$, whereas the bathing solution osmolality was $300 \mathrm{mosM}$. These were measured in each experiment. In addition, the perfusate contained $20 \mu \mathrm{Ci} / \mathrm{ml}$ of an impermeant volume marker, ${ }^{125} \mathrm{I}-$ iothalamate (Abbott Laboratories, Chemical Div., North Chicago, Ill.). All solutions were equilibrated at $37^{\circ} \mathrm{C}$ with $95 \% \mathrm{O}_{2}-5 \% \mathrm{CO}_{2}$ so that the final $\mathrm{pH}$ at $37^{\circ} \mathrm{C}$ was 7.4 . In a few experiments, the $180 \operatorname{mos} M$ osmotic gradient across the tubule was established by making the perfusate isotonic with plasma and the bathing solution hypertonic with raffinose. Because the hydroosmotic action of ADH across the cortical collecting tubule is equally expressed when the bathing solution is hypertonic (6), and because the results obtained in these tubules were identical to those in the other tubules in the same treatment group, all results are presented together. All experiments were conducted at $37^{\circ} \mathrm{C}$.

Because cortical collecting tubules manifest a small osmotic water permeability in the absence of ADH when initially perfused in vitro (7), all tubules were allowed to equilibrate in vitro for $60 \mathrm{~min}$. From 60 to $90 \mathrm{~min}$ after commencing perfusion, control collections were made to measure the osmotic water flux before the addition of ADH. At $90 \mathrm{~min}$, experimental collections were made continuously for collected fluid osmolality and radioactivity. At $37^{\circ} \mathrm{C}$, after reaching the peak value $10-20 \mathrm{~min}$ after its addition, the hydroosmotic response to ADH declines gradually (8). For this reason, the values for $J_{v}$ and $L_{p}$ reported here represent the peak values obtained from each tubule. The time course of the hydroosmotic response to $\mathrm{ADH}$ was identical in tubules obtained from normal and adrenalectomized rabbits.

The net volume flux was given as:

$$
J_{v}=\frac{V_{i}-V_{0}}{L}
$$

where $J_{v}=$ rate of net volume flux in $\mathrm{nl} / \mathrm{mm} \min ; V_{i}=$ perfusion rate in $\mathrm{nl} / \mathrm{min} ; \mathrm{V}_{0}=$ collection rate in $\mathrm{nl} / \mathrm{min}$; and $\mathrm{L}$ $=$ tubular length in $\mathrm{mm}$. The measurement of $\mathrm{J}_{\mathrm{v}}$ does not give a true estimate of the osmotic water permeability of the collecting duct in that it does not take into account the magnitude of the driving force for volume reabsorption, the osmotic gradient. Thus, the hydraulic conductivity coefficient $\left(\mathrm{L}_{\mathrm{p}}\right)$ was used to measure the hydroosmotic response to ADH and was derived as described $(9,10)$ :

$$
L_{p}=\frac{-V_{i} C_{i}}{R T A}\left[\frac{C_{i}-C_{0}}{C_{i} C_{b} C_{0}}+\frac{1}{\left(C_{b}\right)^{2}} \ln \frac{\left(C_{0}-C_{b}\right) C_{i}}{\left(C_{i}-C_{b}\right) C_{0}}\right]
$$

where $\mathrm{L}_{\mathrm{p}}=$ hydraulic conductivity coefficient in $\mathrm{cm} / \mathrm{s}$ atm $\times 10^{7} ; \quad \mathrm{R}=$ gas constant; $\mathrm{T}=$ absolute temperature; $\mathrm{A}$ $=$ internal tubular surface area (with an assumed internal diameter of 20 microns); ${ }^{3} C_{b}=$ osmolality of the bathing solution; $\mathrm{C}_{\mathrm{i}}=$ osmolality of the perfusate; and $\mathrm{C}_{0}=$ osmolality of the collected fluid. The osmolality of the bathing, collected, and perfusate solutions were measured by freezing point de-

${ }^{3}$ The internal diameter of tubules from normal and adrenalectomized rabbits were not different. 
pression in nanoliter quantities (Clifton nanoliter osmometer; Clifton Technical Physics, Hartford, N. Y.).

Study groups. Four groups of in vitro experiments were performed. The experiments of group 1 were performed to determine whether collecting ducts from adrenalectomized rabbits were intrinsically permeable to water in the absence of $\mathrm{ADH}$, and to compare the hydroosmotic response with ADH of collecting ducts from normal and adrenalectomized rabbits. Thus, control collections were made during the initial $90 \mathrm{~min}$ of perfusion of collecting ducts from normal and adrenalectomized rabbits, and the $\mathrm{J}_{\mathrm{v}}$ determined before the addition of ADH. After this time, ADH at a final concentration of $200 \mu \mathrm{U} / \mathrm{ml}$ was added continuously to the bathing solution and the $J_{v}$ and $L_{p}$ determined over the next $120 \mathrm{~min}$ at $5-10$-min intervals.

Group 2 experiments were first designed to determine whether adrenal steroids, by themselves, affected the intrinsic water permeability of collecting ducts from adrenalectomized rabbits; second, whether adrenal steroids affected the blunted hydroosmotic responsiveness of collecting ducts from adrenalectomized rabbits to $\mathrm{ADH}$; and third, whether there was any specificity of the action of adrenal steroids on the hydroosmotic response to ADH. Thus, either aldosterone, dexamethasone, or progesterone, each at a final concentration of $50 \mathrm{pM}$, was singly present in the perfusing solution from the very beginning of the experiment. Tubular fluid was collected from 60 to $90 \mathrm{~min}$ after the beginning of the experiment in the presence of one of the steroids but before the addition of ADH, thereby allowing an examination of the effect that a single steroid might alone have on the intrinsic water permeability across cortical collecting tubules from adrenalectomized rabbits. At $90 \mathrm{~min}, \mathrm{ADH}$ was then added and the $J_{v}$ and $L_{p}$ were measured at continuous intervals.

The experiments of group 3 were designed to determine the hydroosmotic response of tubules from adrenalectomized rabbits to exogenous cyclic AMP in an effort to localize the blunted hydroosmotic response to ADH to either steps involved in the intracellular accumulation of cyclic AMP or, alternatively, to those steps distal to cyclic AMP (see Fig. 6). Thus, as in group 1, after control collections, an analog of cyclic AMP, 8-bromo cyclic AMP (Sigma Chemical Co., St. Louis, Mo.), at a final concentration of $0.1 \mathrm{mM}$, was added continuously to the solution that bathed collecting ducts of normal and adrenalectomized rabbits, and the $L_{p}$ was determined.

The experiments of group 4 were designed to examine whether cyclic AMP phosphodiesterase inhibition restored the hydroosmotic responsiveness of collecting ducts from adrenalectomized rabbits to ADH. Thus, the phosphodiesterase inhibitor, 1-methyl-3-isobutylxanthine (MIX; Aldrich Chemical Co., Inc., Milwaukee, Wis.) was present continuously in the bathing solution from the beginning of the experiment at a final concentration of $0.1 \mathrm{mM}$. Collections of tubular fluid were then made before and after the addition of $2 \mu \mathrm{U} / \mathrm{ml}$ of $A D H$, as in group 1 , and the $J_{v}$ and $L_{p}$ determined. Cortical collecting tubules from normal and adrenalectomized rabbits were studied. In addition, a second series of tubules from normal rabbits were exposed only to ADH at a concentration of $2 \mu \mathrm{U} / \mathrm{ml}$ in the absence of MIX to measure the hydroosmotic response resulting from this lower concentration of ADH.

All data in the text and figures is expressed as the mean \pm SEM. Paired and unpaired $t$ tests were used to determine significance, which was taken as $P<0.05$.

\section{RESULTS}

Maximum urinary osmolality. The maximum urine osmolality was measured in 6 normal and 12 adrenalec- tomized rabbits to determine whether adrenal insufficiency in the rabbit was associated with a concentrating defect. All rabbits drank $0.9 \%$ sodium chloride and were given $1.25 \mathrm{U} / \mathrm{kg}$ vasopressin tannate. As shown in Fig. 1, adrenalectomized rabbits with a maximum urinary osmolality of $1,327 \pm 65$ mosM had a significantly less $(P<0.02)$ concentrated urine then identically treated normal rabbits with a maximum urinary osmolality of $1,901 \pm 207$ mosM.

To determine whether this concentrating defect was a direct result of adrenal steroid absence or some secondary consequence of adrenalectomy, the same 12 adrenalectomized rabbits were given a single injection of either deoxycorticosterone, $250 \mu \mathrm{g} / \mathrm{kg}$, or dexamethasone, $50 \mu \mathrm{g} / \mathrm{kg}$, and the maximum urine osmolality after vasopressin determined again. As shown in Fig. 1,

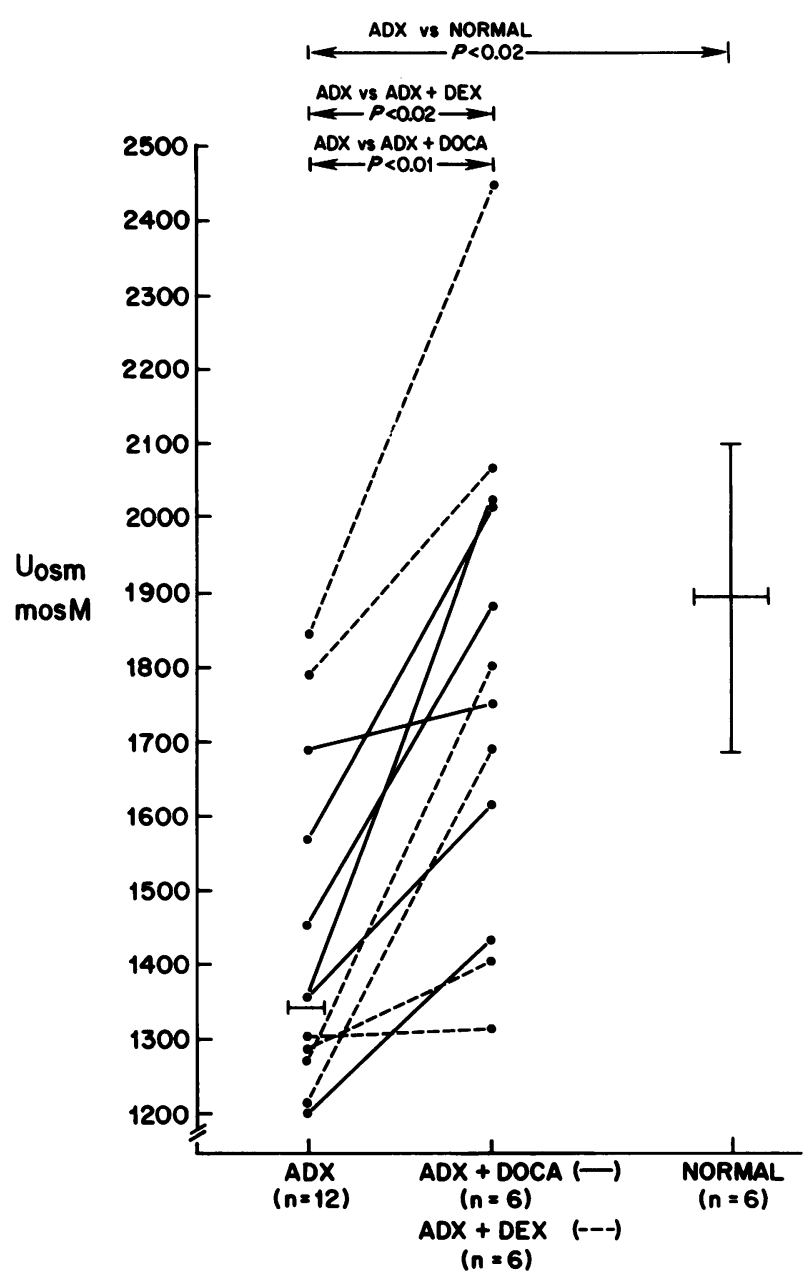

FIGURE 1 The effect of adrenalectomy and the selective replacement of mineralo- or glucocorticoid hormones on the maximum urinary concentrating ability in normal and adrenalectomized (ADX) rabbits. Maximum urinary osmolality was determined after the administration of $1.25 \mathrm{U} / \mathrm{kg}$ ADH. ADX rabbits were retested after either deoxycorticosterone (DOCA) (solid lines), $250 \mu \mathrm{g} \mathrm{kg}$, or dexamethasone (DEX) (broken lines), $50 \mu \mathrm{g} / \mathrm{kg}$. 
either deoxycorticosterone $(P<0.01)$ or dexamethasone $(P<0.02)$ significantly increased the maximum urinary osmolality to or toward normal in both groups of rabbits ( $P=$ NS compared with normal).

Group 1. The basal $\mathrm{J}_{\mathrm{v}}$ before the addition of ADH was not different from zero across cortical collecting tubules from both normal and adrenalectomized rabbits (Table $\mathrm{I}$; group $1, \mathrm{~J}_{\mathrm{v}}$ before). Thus, these experiments suggest that collecting ducts from adrenalectomized rabbits are not intrinsically permeable to water before the addition of $\mathrm{ADH}$.
To determine whether the concentrating defect seen in adrenalectomized rabbits in vivo could involve alterations in the response of the collecting duct to $\mathrm{ADH}$, cortical collecting tubules from normal and adrenalectomized rabbits were perfused in vitro and the hydroosmotic response to a maximal concentration of $\mathrm{ADH}$ was determined. As shown in Table I (group 1) and Fig. 2, the $\mathrm{L}_{\mathrm{p}}$ across cortical collecting tubules from normal rabbits after $A D H$ was $275 \pm 39 \mathrm{~cm} / \mathrm{s}$ atm $\times 10^{7}$, a value similar to that reported by others under comparable experimental conditions (8). This

TABLE I

Hydroosmotic Response across Cortical Collecting Tubules from Normal and Adrenalectomized Rabbits

\begin{tabular}{|c|c|c|c|c|c|c|c|}
\hline \multirow{2}{*}{$\begin{array}{l}\text { Experimental } \\
\text { group }\end{array}$} & \multirow[b]{2}{*}{$\mathrm{L}$} & \multirow[b]{2}{*}{$\mathrm{v}_{\mathrm{i}}$} & \multirow{2}{*}{$\begin{array}{l}\text { Collected } \\
\text { Osm }\end{array}$} & \multicolumn{2}{|c|}{$\mathbf{J}_{\mathbf{v}}$} & \multirow{2}{*}{$\begin{array}{l}\mathrm{L}_{\mathrm{D}} \\
\text { after }\end{array}$} & \multirow[b]{2}{*}{$P t$} \\
\hline & & & & Before* & After* & & \\
\hline
\end{tabular}

Group I

Normal $+200 \mu \mathrm{U} / \mathrm{ml}$ ADH $(n=7)$

$\begin{array}{rccrrrr}2.18 & 12.05 & 193 \S & 0.03 & 1.74 & 275 & \\ \pm 0.15 & \pm 1.05 & \pm 11 & \pm 0.02 & \pm 0.27 & \pm 39 & \\ +200 \mu \mathrm{M} / \mathrm{ml} \mathrm{ADH} & (n=9) & & & & \\ 1.89 & 9.11 & 143 \S & 0.00 & 0.39 & 48 & <0.0005 \\ \pm 0.13 & \pm 0.92 & \pm 6 & \pm 0.02 & \pm 0.04 & \pm 5 & \end{array}$

Group II

Adrenalectomized $+50 \mathrm{pM}$ Aldosterone $+200 \mu \mathrm{U} / \mathrm{ml}$ ADH $(n=6)$

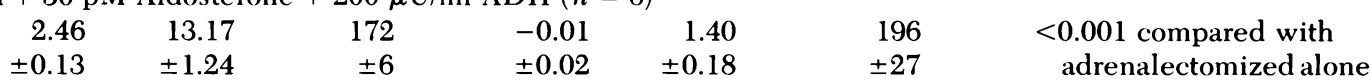

Adrenalectomized $+50 \mathrm{pM}$ dexamethasone $+200 \mu \mathrm{U} / \mathrm{ml}$ ADH $(n=6)$

$\begin{array}{ccccccc}2.06 & 12.49 & 154 & 0.00 & 1.08 & 155 & <0.005 \text { compared with } \\ \pm 0.07 & \pm 0.94 & \pm 7 & \pm 0.01 & \pm 0.25 & \pm 32 & \text { adrenalectomized alone } \\ +50 \mathrm{pM} \text { progesterone } & +200 \mu \mathrm{U} / \mathrm{ml} & \mathrm{ADH}(n=4) & & & \\ 2.32 & 12.24 & 140 & 0.01 & 0.56 & 60 & \text { NS compared with } \\ \pm 0.29 & \pm 0.62 & \pm 3 & \pm 0.01 & \pm 0.05 & \pm 8 & \text { adrenalectomized alone }\end{array}$

Group III

Normal + 0.1 mM 8-bromo cyclic AMP $(n=5)$

\begin{tabular}{|c|c|c|c|c|}
\hline 2.22 & 13.07 & 193 & 0.01 & 2.00 \\
\hline \pm 0.23 & \pm 1.07 & \pm 14 & \pm 0.01 & \pm 0.21 \\
\hline
\end{tabular}

Adrenalectomized $+0.1 \mathrm{mM}$ 8-bromo cyclic $\operatorname{AMP}(n=5)$

\begin{tabular}{|c|c|c|c|c|c|c|}
\hline 1.97 & 10.72 & 185 & 0.03 & 2.09 & 268 & NS compared with normal \\
\hline \pm 0.12 & \pm 1.00 & \pm 12 & \pm 0.02 & \pm 0.34 & \pm 50 & \\
\hline
\end{tabular}

Group IV

Normal $+2 \mu \mathrm{U} / \mathrm{ml}$ ADH $(n=5)$

$\begin{array}{rrrrrr}2.14 & 13.94 & 160 & -0.01 & 1.38 & 175 \\ \pm 0.20 & \pm 0.38 & \pm 7 & \pm 0.01 & \pm 0.10 & \pm 23\end{array}$

Normal $+0.1 \mathrm{mM}$ 1-methyl-3-isobutylxanthine $+2 \mu \mathrm{U} / \mathrm{ml}$ ADH $(n=7)$

$\begin{array}{rrrrrr}2.11 & 12.27 & 230 & 0.02 & 2.71 & 467 \\ \pm 0.08 & \pm 0.66 & \pm 14 & \pm 0.01 & \pm 0.30 & \pm 74\end{array}$

Adrenalectomized $+0.1 \mathrm{mM}$ 1-methyl-3-isobutylxanthine $+2 \mu \mathrm{U} / \mathrm{ml} \mathrm{ADH}(n=5)$

$\begin{array}{rrrrrr}2.04 & 10.27 & 234 & 0.03 & 2.44 & 503 \\ \pm 0.14 & \pm 0.56 & \pm 16 & \pm 0.02 & \pm 0.23 & \pm 133\end{array}$

$<0.05$ compared with normal + ADH alone

NS compared with normal + MIX + ADH

* The values reported are the maximum observed before and after the addition to the bathing solution of either ADH or 8-bromo cyclic AMP. All other agents were present from the beginning of the experiment, whereas either ADH or 8-bromo cyclic AMP was added 90 min after the beginning of the experiment.

$\ddagger$ Refers to $\mathrm{L}_{\mathrm{p}}$ values.

$\$$ In some of these experiments the perfusate was isotonic and the bathing solution hypertonic, although the osmotic gradient was identical to the rest of the experiments in this group. Because the results were identical, these experiments are included. 


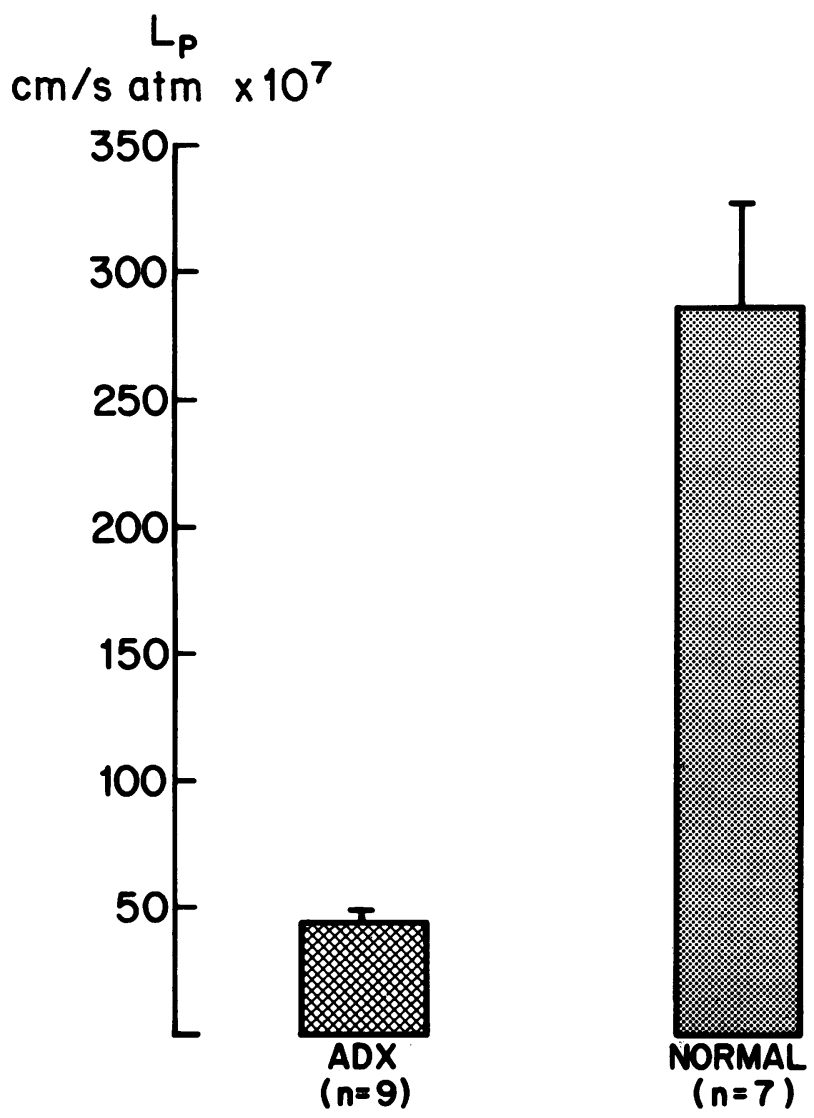

FIgURE 2 The hydroosmotic response to ADH across cortical collecting tubules from normal and adrenalectomized (ADX) rabbits. The $\mathrm{L}_{\mathrm{p}}$ was measured after the addition of $200 \mu \mathrm{U} / \mathrm{ml} \mathrm{ADH}$ to the solution bathing tubules in vitro. $P<0.0005$.

was significantly greater $(P<0.0005)$ than the similarly determined $\mathrm{L}_{\mathrm{p}}$ across cortical collecting tubules from adrenalectomized rabbits after $\mathrm{ADH}$, which had a value of $48 \pm 5 \mathrm{~cm} / \mathrm{s}$ atm $\times 10^{7}$.

Group 2. Although the in vivo administration of either deoxycorticosterone or dexamethasone corrected the concentrating defect in adrenalectomized rabbits, the blunted hydroosmotic response across cortical collecting tubules from these rabbits could be the result of some secondary systemic consequence of adrenal insufficiency or the result of a direct effect of steroids on the epithelium of the collecting duct. To examine whether adrenal steroids had a direct effect on the hydroosmotic response of the epithelium of the collecting duct to $\mathrm{ADH}$, cortical collecting tubules from adrenalectomized rabbits were exposed in vitro to either aldosterone, dexamethasone, or progesterone, each at a final concentration of $50 \mathrm{pM}$, and the net osmotic water permeability measured before and after the addition of ADH. As shown in Table I (group 2, $\mathrm{J}_{\mathrm{v}}$ before) before the addition of $\mathrm{ADH}$, the exposure of collecting ducts from adrenalectomized rabbits to either aldosterone, dexamethasone, or progesterone resulted in a $\mathrm{J}_{\mathrm{v}}$ of zero. Thus, none of the steroids tested altered the intrinsic water impermeability of the collecting duct before the addition of $\mathrm{ADH}$.

The results of steroid addition on the hydroosmotic response to $\mathrm{ADH}$ are shown in Table I (group 2) and Fig. 3, where it can be seen that either aldosterone or dexamethasone significantly increased $(P<0.001$, $P<0.005$, respectively) the $L_{p}$ after ADH, from $48 \pm 5$ to $196 \pm 27$ and $155 \pm 32 \mathrm{~cm} / \mathrm{s}$ atm $\times 10^{7}$, respectively. Progesterone did not significantly increase the hydroosmotic response to $A D H$, with the resultant $L_{p}$ being only $60 \pm 8 \mathrm{~cm} / \mathrm{s} \mathrm{atm} \times 10^{7}(P=\mathrm{NS})$.

Group 3. The locus of this "permissive" effect of adrenal steroids on the hydroosmotic response to ADH could reside anywhere along the pathway of the ADH response in the collecting duct, from the binding of $\mathrm{ADH}$ to its receptor on the antiluminal side of the cell (11) to the apical plasma membrane, the ultimate barrier for water reabsorption (12). We attempted to determine whether adrenal steroids were acting to increase the rate of intracellular accumulation of cyclic AMP or whether steroids affected some step distal to cyclic AMP accumulation through the use of a permeable analog of the nucleotide, 8-bromo cyclic AMP (see Fig. 6 in the discussion section for review

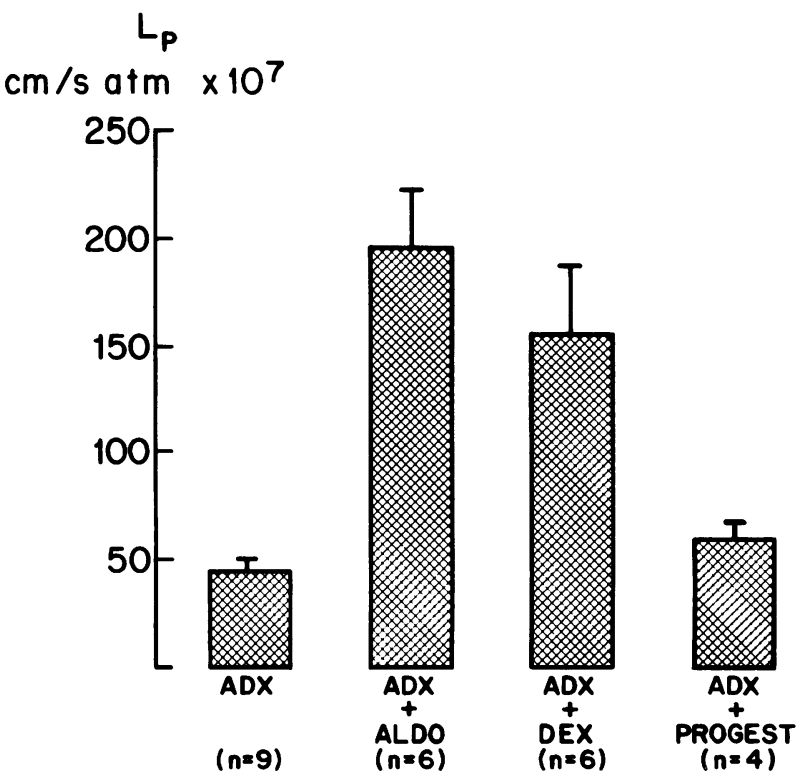

FIGURE 3 The effect of the in vitro addition of a single steroid on the hydroosmotic response across cortical collecting tubules from adrenalectomized (ADX) rabbits to ADH. Either aldosterone alone (ALDO), dexamethasone alone (DEX), or progesterone alone (PROGEST) was added to the perfusate at a final concentration of $50 \mathrm{pM}$; the $\mathrm{L}_{\mathrm{p}}$ after $200 \mu \mathrm{U} / \mathrm{ml}$ ADH was measured. ADX vs. ALDO, $P<0.001$; ADX vs. DEX, $P<0.005$; ADX vs. PROGEST, $P=N S$; ALDO vs. DEX, $P=$ NS. 
of the relevant biochemical steps). The analog alone was added to the solution that bathed cortical collecting tubules from normal and adrenalectomized rabbits, and the resultant hydroosmotic response was determined. These experiments are presented in Table I (group 3) and Fig. 4, where it can be seen that 8-bromo cyclic AMP increased the $L_{p}$ across cortical collecting tubules from normal rabbits to $286 \pm 29 \mathrm{~cm} / \mathrm{s}$ atm $\times 10^{7}$, a value similar to that seen after the addition of $200 \mu \mathrm{U} / \mathrm{ml}$ ADH to tubules from normal rabbits. Under the same experimental conditions, 8-bromo cyclic AMP increased the $L_{p}$ across cortical collecting tubules from adrenalectomized rabbits to $268 \pm 50 \mathrm{~cm} / \mathrm{s}$ atm $\times 10^{7}$, a value virtually identical to that obtained from tubules of normal rabbits.

Group 4. The results of the experiments of group 3 suggest that the blunted hydroosmotic response of tubules from adrenalectomized rabbits to $\mathrm{ADH}$ involves a diminished rate of intracellular cyclic AMP accumulation. To further investigate the possibility that adrenal steroids act to increase the rate of intracellular cyclic AMP accumulation, cortical collecting tubules from normal and adrenalectomized rabbits were perfused in the continual presence of a potent phosphodiesterase inhibitor, MIX, and the hydroosmotic re-
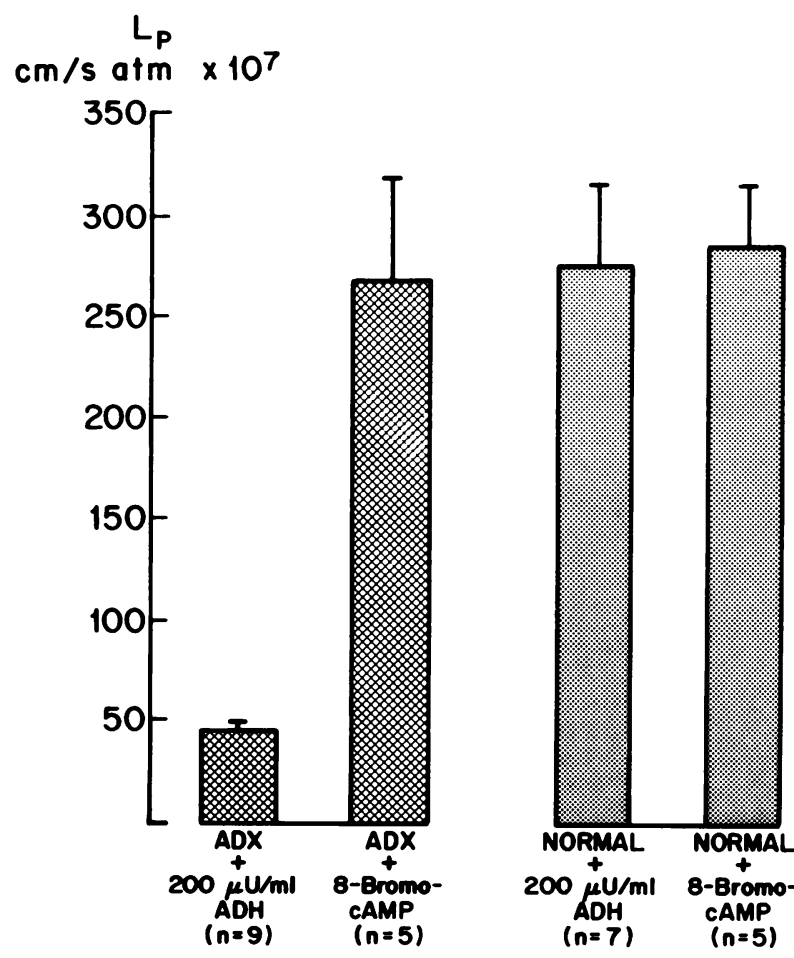

Figure 4 The hydroosmotic response across cortical collecting tubules from normal and adrenalectomized (ADX) rabbits after a cyclic AMP analog. 8-bromo cyclic AMP was added to the solution that bathed cortical collecting tubules from normal and ADX rabbits, and the $\mathrm{L}_{p}$ was measured. sponse to a submaximal concentration of $\mathrm{ADH}$ was determined. As shown in Table I (group 4) and Fig. 5, cortical collecting tubules from normal rabbits, when exposed to $2 \mu \mathrm{U} / \mathrm{ml}$ of ADH without MIX, responded with a $L_{p}$ of $175 \pm 32 \mathrm{~cm} / \mathrm{s}$ atm $\times 10^{7}$. The addition of MIX plus $2 \mu \mathrm{U} / \mathrm{ml} \mathrm{ADH}$ to tubules from normal rabbits resulted in a significantly greater $L_{p}, 467 \pm 76$ $\mathrm{cm} / \mathrm{s}$ atm $\times 10^{7} \quad(P<0.05)$. When cortical collecting tubules from adrenalectomized rabbits were exposed to MIX plus $2 \mu \mathrm{U} / \mathrm{ml} \mathrm{ADH}$, the resultant $\mathrm{L}_{\mathrm{p}}$ was $503 \pm 133 \mathrm{~cm} / \mathrm{s}$ atm $\times 10^{7}$, a value that did not differ from that obtained from tubules of normal rabbits identically treated $(P=\mathrm{NS})$.

\section{DISCUSSION}

The present study demonstrates that the rabbit, like man (4), dog (13), and rat (14), is unable to generate a maximally concentrated urine when rendered adrenally insufficient. Previous studies have revealed a diminished medullary tonicity associated with adrenal insufficiency $(13,14)$, and have suggested that the in-
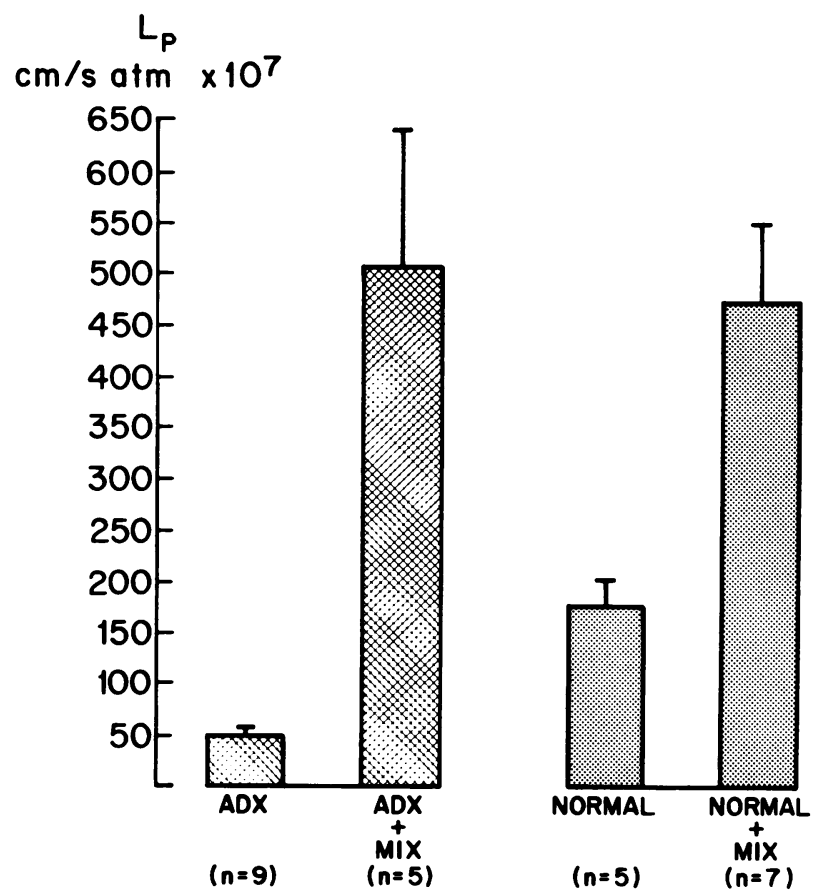

FIGURE 5 The effect of the addition of a phosphodiesterase inhibitor on the hydroosmotic response to a submaximal concentration of ADH. Cortical collecting tubules from normal or adrenalectomized (ADX) rabbits were exposed to $0.1 \mathrm{mM}$ MIX in the bathing solution, and the $\mathrm{L}_{\mathrm{p}}$ after the addition of $2 \mu \mathrm{U} / \mathrm{ml}$ ADH to the bath was measured. Cortical collecting tubules from normal rabbits exposed only to $2 \mu \mathrm{U} / \mathrm{ml}$ ADH, or from ADX rabbits exposed to $200 \mu \mathrm{U} / \mathrm{ml} \mathrm{ADH}$, are shown for comparison. ADX vs. ADX + MIX, $P<0.001$; NORMAL vs. NORMAL + MIX, $P<0.05$; NORMAL vs. ADX, $P<0.0005 ; \mathrm{ADX}+\mathrm{MIX}$ vs. NORMAL + MIX, $P=$ NS. 
ability to concentrate maximally was the result of a diminished driving force for water reabsorption secondary to a steroid-dependent decrease in solute transport by the thick ascending limb of Henle. Whether in fact the thick ascending limb of Henle is physiologically responsive to adrenal steroids is unclear at this time. Using the activity of the tricarboxylic acid cycle enzyme, citrate synthase, as a marker for the action of aldosterone (15), we have recently demonstrated that the activity of the enzyme in the cortical thick ascending limb of Henle is unchanged by adrenalectomy or the addition of exogenous aldosterone, whereas in the cortical collecting tubule, adrenalectomy is associated with a diminution of citrate synthase activity, and aldosterone treatment with a significant increase in activity (16).

The present study reveals that cortical collecting tubules from adrenalectomized rabbits are not osmotically "leaky" before the addition of ADH (Table I). Thus, we find no evidence to support the concept suggested from in vivo micropuncture studies (17) that the inability of adrenalectomized animals to excrete excess water is the result of a steroid-dependent loss of the basal impermeability of the distal nephron. The principal difference between these earlier studies and the present work is that the present study was conducted in vitro, where a direct examination of the intrinsic function of the tubular epithelium, isolated from all systemic influences, is possible.

The present study does reveal that cortical collecting tubules from adrenalectomized rabbits demonstrate a markedly blunted hydroosmotic response to $\mathrm{ADH}$ (Fig. 2). This diminution in the hydroosmotic effectiveness of ADH across the collecting duct could partly account for the inability to generate a maximally concentrated urine in adrenal insufficiency. When adrenalectomized rabbits were given either deoxycorticosterone or dexamethasone in vivo they were able to increase significantly the maximum osmolality of their urine after exogenous ADH (Fig. 1). When cortical collecting tubules isolated from adrenalectomized rabbits were exposed to either aldosterone or dexamethasone, but not progesterone, they were able to respond to ADH with a significant increase in water reabsorption (Fig. 3). None of the steroids alone had any effect on the intrinsic water permeability of collecting ducts from adrenalectomized rabbits (Table I, group $2, \mathrm{~J}_{\mathrm{v}}$ before) in that the net water movement before the addition of ADH was zero. Thus, as originally defined by Ingle (18), these effects of adrenal steroids are permissive in that they have no effect themselves on the water permeability of the collecting duct but act to augment the response to a second hormone, ADH. This permissive effect of adrenal steroids was expressed after $90 \mathrm{~min}$ of exposure and at a concentration of $50 \mathrm{pM}$, suggesting that it represents a physio- logically significant effect. Although this data does not indicate whether the in vivo administration of either adrenal steroid acted solely on the collecting duct in vivo, it does suggest that at least part of the concentrating defect seen in adrenalectomized animals is referable to an inability of the collecting duct to reabsorb water under the influence of $\mathrm{ADH}$.

In an effort to explore the mechanism(s) involved in the permissive effect of adrenal steroids on the hydroosmotic response to $\mathrm{ADH}$, cortical collecting tubules from normal and adrenalectomized rabbits were exposed to $0.1 \mathrm{mM} 8$-bromo cyclic AMP in vitro and the resultant $L_{p}$ determined (Fig. 4). This concentration of the cyclic AMP analog has been shown previously to induce maximal water reabsorption across cortical collecting tubules from normal rabbits studied under conditions similar to those used in the present study (8). In the present study, 8-bromo cyclic AMP induced a $\mathrm{L}_{\mathrm{p}}$ across tubules from normal rabbits, comparable with that induced by a maximum concentration of $\mathrm{ADH}$. When cortical collecting tubules from adrenalectomized rabbits were exposed to the same concentration of 8-bromo cyclic AMP, the resultant $L_{p}$ was virtually identical to that observed across tubules from normal rabbits. This suggests that the inability of collecting ducts to respond to ADH in the absence of adrenal steroids is the result of a diminished rate of intracellular cyclic AMP accumulation rather than a defect at some site distal to cyclic AMP (Fig. 6).

To further explore the mechanism(s) of the permissive effect of adrenal steroids on the action of ADH, the effect of the addition of $0.1 \mathrm{mM}$ of a potent phosphodiesterase inhibitor, MIX, on the hydroosmotic

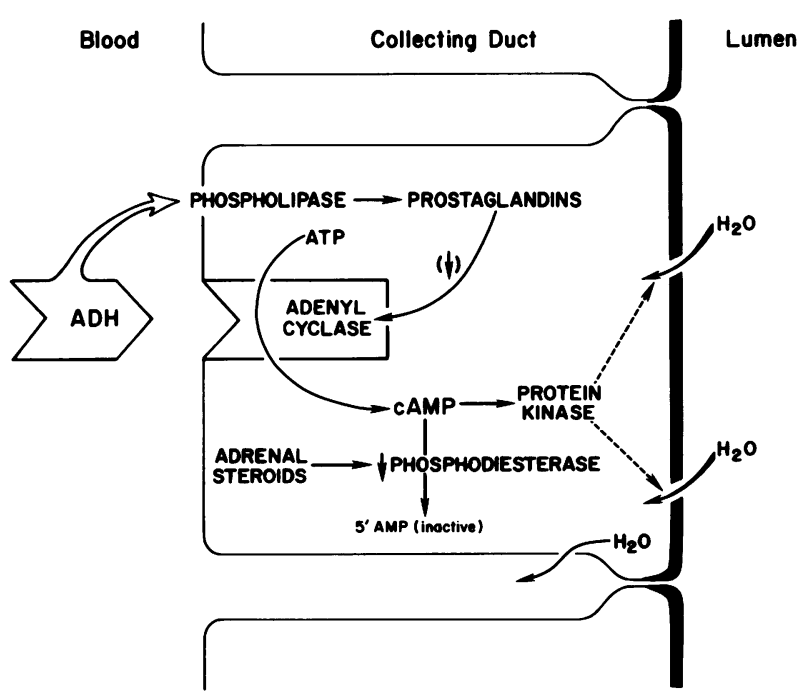

FIGURE 6 A summary of our current understanding of the hormonal control of the hydroosmotic response to $\mathrm{ADH}$ in the mammalian collecting duct. 
response to a submaximal $(2 \mu \mathrm{U} / \mathrm{ml})$ concentration of ADH was determined (Fig. 5). This concentration of MIX has been shown to maximally inhibit rabbit renal medullary phosphodiesterase (19). As reported by others (19), the present study demonstrates that the addition of MIX increased the hydroosmotic response of cortical-collecting tubules from normal rabbits to a submaximal concentration of ADH (Fig. 5, right), a finding consistent with phosphodiesterase inhibition. When cortical collecting tubules from adrenalectomized rabbits were perfused under identical conditions, MIX plus $2 \mu \mathrm{U} / \mathrm{ml} \mathrm{ADH}$, the resulting hydroosmotic response was not different from that observed across tubules of normal rabbits (Fig. 5, left).

The results of the present study are comparable with those reported previously in the toad urinary bladder, an epithelium often studied as a model of the mammalian collecting duct. When the toad urinary bladder was rendered steroid-deplete, it became hydroosmotically unresponsive to ADH (20). The addition of very low concentrations of either a mineralo- or glucocorticoid hormone in vitro restored the hydroosmotic responsiveness to ADH. As in the present study, mineralo- and glucocorticoid steroid hormones were essentially equipotent in their permissive effects. The addition of a phosphodiesterase inhibitor to the steroid-depleted toad urinary bladder restored the hydroosmotic responsiveness to ADH, and when the actual activity of phosphodiesterase was measured in cells scraped from steroid-depleted toad urinary bladders, it was elevated (21). The addition of either aldosterone or dexamethasone to the toad urinary bladder was associated with a diminution in phosphodiesteräse activity, and the permissive effect of adrenal steroids was dependent on RNA transcription and protein synthesis.

Fig. 6 represents our present understanding of the hormonal control of ADH-mediated water reabsorption in the mammalian collecting duct cell.

We interpret the results depicted in Figs. 4 and 5 to be consistent with the hypothesis that steps distal to cyclic AMP are not rate limiting in the absence of steroids and that at least one site of action of adrenal steroids in exerting their permissive effects on the hydroosmotic response to ADH involves the rate of cyclic AMP accumulation. Because the cyclic AMP analog mimicked the action of $\mathrm{ADH}$ in tubules from normal rabbits (Fig. 4), its efficacy in inducing water reabsorption across cortical collecting tubules from adrenalectomized rabbits suggests that adrenal steroids act to increase the rate of endogenous cyclic AMP accumulation. As shown in Fig. 6, this could involve either an increased rate of generation by adenyl cyclase or a diminution in the rate of cyclic AMP degradation by phosphodiesterase (or both).

It is not possible to distinguish between these two possibilities from the data displayed in Fig. 4 in that the cyclic AMP analog not only acts to bypass those steps involved in endogenous cyclic AMP generation but, because the analog is resistant to hydrolysis by phosphodiesterase (22), could as well suggest an increased activity of endogenous cyclic AMP degradation in the absence of adrenal steroids. The experiments of Fig. 5 show that the addition of a phosphodiesterase inhibitor restored to normal the hydroosmotic response of tubules from adrenalectomized rabbits, a finding consistent with at least one effect of adrenal steroids being the attenuation of the activity of phosphodiesterase. Such a conclusion would require the direct determination of cyclic AMP-dependent phosphodiesterase activity in single segments of cortical collecting tubule taken from normal and adrenalectomized rabbits. Unfortunately such an assay is not available for isolated tubule segments, and the next best set of experiments were therefore performed using the most specific inhibitor of phosphodiesterase available, MIX. It is of interest, however, that whole kidney phosphodiesterase activity is greater in adrenalectomized than normal rats, and that the in vivo administration of glucocorticoid hormone returns whole kidney phosphodiesterase activity to normal levels (23).

In addition to a postulated effect of adrenal steroids in modulating phosphodiesterase activity, the results depicted in Fig. 5 are also compatible with the possibility that adrenal steroids act to increase the rate of cyclic AMP generation in response to ADH. This could be mediated, for example, by diminishing the rate of endogenous prostaglandin E (PGE) biosynthesis. In the toad urinary bladder, adrenal steroid depletion is associated with an increased rate of endogenous PGE synthesis that is restored to normal by low concentrations of either aldosterone or dexamethasone (24). PGE has been shown to inhibit the hydroosmotic action of ADH across isolated perfused cortical collecting tubules (25), partly by a direct inhibition of adenyl cyclase (26). As shown in Fig. 6, ADH itself acts to stimulate the endogenous synthesis of PGE in both the toad urinary bladder (24) and rabbit renal medullary interstitial cell cultures (27), and the biosynthetic enzyme for PGE, cyclooxygenase, has been identified in cortical collecting duct cells $(28,29)$. A direct demonstration of PGE synthesis by the cortical collecting duct has not been reported, and whether the collecting duct, like the toad bladder, responds to steroid depletion with an increase in the rate of PGE synthesis is unknown.

Whereas the physiologic and clinical significance of the present studies is conjectural, the following conclusions seem warranted: the isosthenuria of Addison's disease is the result of derangement of many physiological regulatory processes; the inability to concentrate the urine maximally in Addison's disease is partly 
the result of an inability of the collecting duct to respond to $\mathrm{ADH}$ with an increase in water reabsorption; this loss of responsiveness is the result of a direct effect of adrenal steroids on the epithelium of the collecting duct and partly involves a diminished rate of cyclic AMP accumulation.

\section{ACKNOWLEDGMENTS}

The authors gratefully acknowledge the excellent technical assistance of Sharon Bracey, Susan Corona, and James Harrison.

This work was supported in part by National Institute of Arthritis and Metabolic Diseases Research grant 1-R01-AM14677 and U. S. Public Health Service Training grant 5-T32-AM-07257.

\section{REFERENCES}

1. Robinson, F. J., M. H. Power, and E. J. Kepler. 1941. Two new procedures to assist in the recognition and exclusion of Addison's disease: a preliminary report. Proc. Staff Meet. Mayo Clin. 16: 577-586.

2. Boykin, J., A. deTorrenté, A. Erickson, G. Robertson, and R. W. Schrier. 1978. Role of plasma vasopressin in impaired water excretion of glucocorticoid deficiency. J. Clin. Invest. 62: 738-744.

3. Green, H. H., A. R. Harrington, and H. Valtin. 1970. On the role of antidiuretic hormone in the inhibition of acute water diuresis in adrenal insufficiency and the effects of gluco- and mineralocorticoids in reversing the inhibition. J. Clin. Invest. 49: 1724-1736.

4. Willson, D. M., and F. W. Sunderman. 1939. Studies in serum electrolytes. XII. The effect of water restriction in a patient with Addison's disease receiving sodium chloride. J. Clin. Invest. 18: 35-43.

5. Stokes, J. B., and J. P. Kokko. 1977. Inhibition of sodium transport by prostaglandin $\mathrm{E}_{2}$ across the isolated, perfused rabbit collecting tubule. J. Clin. Invest. 59: 1099-1104.

6. Schafer, J. A., and T. E. Andreoli. 1972. The effect of antidiuretic hormone on solute flows in mammalian collecting tubules. J. Clin. Invest. 51: 1279-1286.

7. Grantham, J. J., and M. B. Burg. 1966. Effect of vasopressin and cyclic AMP on the permeability of isolated collecting ducts. Am. J. Physiol. 211: 255-259.

8. Fine, L., D. Schlondorff, W. Trizna, R. M. Gilbert, and N. S. Bricker. 1978. Functional profile of the uremic nephron. Impaired water permeability and adenyl cyclase responsiveness of the cortical collecting tubule to vasopressin. J. Clin. Invest. 61: 1519-1527.

9. DuBois, R., A. Verniory, and M. Abramow. 1976. Computation of the osmotic water permeability of perfused tubule segments. Kidney Int. 10: 478-479.

10. Grantham, J. J., J. M. Irish, and D. A. Hall. 1978. Studies of isolated renal tubules in vitro. Annu. Rev. Physiol. 40: 249-277.

11. Bockaert, J., C. Roy, R. Rajerison, and S. Jard. 1973. Specific binding of ${ }^{3} \mathrm{H}$-lysine-vasopressin to pig kidney plasma membranes. J. Biol. Chem. 248: 5922-5931.

12. Grantham, J. J., C. E. Ganote, M. B. Burg, and J. Orloff.
1969. Paths of transtubular water flow in isolated renal collecting tubules. J. Cell. Biol. 41: 562-576.

13. Cooke, R. C., and R. W. Steenburg. 1973. Effects of aldosterone and cortisol on the renal concentrating mechanism. J. Lab. Clin. Med. 82: 784-792.

14. Sigler, M. H., J. N. Forrest, and J. R. Elkington. 1965. Renal concentrating ability in the adrenalectomized rat. Clin. Sci. (Oxf.). 28: 29-37.

15. Law, P. Y., and I. S. Edelman. 1978. Induction of citrate synthase by aldosterone in the rat kidney. J. Membr. Biol. 41: 41-64.

16. Marver, D., and M. J. Schwartz. 1980. Identification of mineralocorticoid target sites in the isolated rabbit cortical nephron. Proc. Natl. Acad. Sci. U. S. A. 77: In press.

17. Stolte, H., J. P. Brecht, M. Wiederholt, and K. Hierholzer. 1968. Einflub von adrenalektomie und glucocorticoiden auf die wasserpermeabilitat corticaler nephronabschnitte der ratteniere. Pfuegers Arch. 299: 99-127.

18. Ingle, D. J. 1952. The role of the adrenal cortex in homeostasis. J. Endocrinol. 8: XXII.

19. Hall, D. A., L. D. Barnes, and T. P. Dousa. 1977. Cyclic AMP in action of antidiuretic hormone: effects of exogenous cyclic AMP and its new analogue. Am. J. Physiol. 232: F368-F376.

20. Stoff, J. S., J. S. Handler, and J. Orloff. 1972. The effect of aldosterone on the accumulation of adenosine $3^{\prime}, 5^{\prime}$ cyclic monophosphate in toad bladder epithelial cells in response to vasopressin and theophylline. Proc. Natl. Acad. Sci. U. S. A. 69: 805-808.

21. Stoff, J. S., J. S. Handler, A. S. Preston, and J. Orloff. 1973. The effect of aldosterone on cyclic nucleotide phosphodiesterase activity in toad urinary bladder. Life Sci. 13: 545-552.

22. Muneyama, K., R. J. Bauer, D. A. Shuman, R. K. Robins, and L. N. Simon. 1971. Chemical synthesis and biological activity of 8-substituted adenosine $3^{\prime}, 5^{\prime}$-cyclic monophosphate derivatives. Biochemistry. 10: 2390-2395.

23. Senft, G., S. Schultz, K. Munskee, and M. Hoffmann. 1968. Effects of glucocorticoids and insulin on $3^{\prime}, 5^{\prime}$-adenosine monophosphate phosphodiesterase activity in adrenalectomized rats. Diabetologia. 4: 330-335.

24. Zusman, R. M., H. R. Keiser, and J. S. Handler. 1978. Effect of adrenal steroids on vasopressin-stimulated PGE synthesis and water flow. Am. J. Physiol. 234: F532-F540.

25. Grantham, J. J., and J. Orloff. 1968. Effect of prostaglandin $\mathrm{E}_{1}$ on the permeability response of the isolated collecting tubule to vasopressin, adenosine $3^{\prime}, 5^{\prime}$-monophosphate and theophylline. J. Clin. Invest. 47: 11541161 .

26. Beck, N. P., T. Kaneko, U. Zor, J. B. Field, and B. B. Davis. 1971. Effects of vasopressin and prostaglandin $E_{1}$ on the adenyl cyclase-cyclic 3',5'-adenosine monophosphate system on the renal medulla of the rat. J. Clin. Invest. 50: 2461-2465.

27. Zusman, R. M., and H. R. Keiser. 1977. Prostaglandin biosynthesis by rabbit renomedullary interstitial cells in tissue culture. J. Clin. Invest. 60: 215-223.

28. Bohman, S. O. 1977. Demonstration of prostaglandin synthesis in collecting duct cells and other cell types of the rabbit renal medulla. Prostaglandins. 14: 729-744.

29. Smith, W. L., and T. G. Bell. 1978. Immunohistochemical localization of the prostaglandin-forming cyclooxygenase in renal cortex. Am. J. Physiol. 235: F451-F457. 